\title{
KAJIAN EKONOMI TENAGA KERJA SUB SEKTOR PERKEBUNAN TEMBAKAU BERBASIS GENDER (STUDI KASUS DI DESA SUBOH KECAMATAN KABUPATEN SITUBONDO)
}

\author{
Khoirul Efendi1), Sulistyaningsih ${ }^{2 *}$ \\ Fakultas Pertanian, Universitas Abdurachman Saleh Situbondo \\ *Email Korespondensi : lis_sulistyaningsih@yahoo.com
}

\begin{abstract}
Abstrak
Sektor perkebunan di Indonesia setiap tahunnya terus berkembang. Perkembangan sektor perkebunan memiliki arti penting dalam pengembangan pertanian baik skala regional maupun nasional tembakau menjadi salah satu komoditas paling banyak dikembangkan di indonesia selain kelapa sawit. Penyerapan tenaga kerja sub sektor perkebunan khususnya pada komoditi tembakau masih ada ketimpangan, bidang ini masih banyak dijumpai kesenjangan/ketidakadilan gender. Minimnya partisipasi perempuan dalam proses pembangunan khususnya bidang pertanian, membuat program-program yang dijalankan kurang dapat memberikan keadilan kepada perempuan. Pengambil kebijakan umumnya telah membuat banyak kebijakan berkaitan dengan partisipasi perempuan dan keadilan gender untuk pelaksanaan program. Akan tetapi di tingkat pelaksana lapangan ada kesulitan untuk mengimplementasikan program secara lebih berpartisipatif dan berkeadilan bagi perempuan. Penyerapan tenaga kerja laki-laki dan perempuan pada usahatani tembakau di Desa Suboh Kecamatan Suboh Kabupaten Situbondo mulai dari persiapan lahan sampai dengan panen dalam usahatani tembakau yang telah dikonversiakan menjadi 1 hektar yaitu tenaga kerja laki-laki sebesar 71 \% (165 orang) dan tenaga kerja perempuan $29 \%$ (69 orang).
\end{abstract}

Kata Kunci : Tenaga kerja, Tembakau, Gender

\begin{abstract}
The plantation sector in Indonesia continues to grow every year. The development of the plantation sector has an important meaning in the development of agriculture both regional and national scale tobacco has become one of the most widely developed commodities in Indonesia besides oil palm. Absorption of labor in the plantation sub-sector, especially in the commodity of tobacco, there is still an imbalance, this field is still found many gender inequalities / inequalities. The lack of women's participation in the development process, especially in agriculture, makes the programs that are run less able to provide justice to women. Policy makers have generally made many policies relating to women's participation and gender justice for program implementation. However, at the level of field implementers there are difficulties in implementing programs that are more participatory and equitable for women. Absorption of male and female laborers in tobacco farming in Suboh Village, Suboh Subdistrict, Situbondo Regency, from land preparation to harvesting in tobacco farming which has been converted to 1 hectare, namely 71\% of male workers (165 people) and laborers female 29\% (69 people).
\end{abstract}

Keyword : Labor, Tobacco, Gender 


\section{PENDAHULUAN}

Sektor pertanian merupakan sektor unggulan bagi perkembangan Indonesia, hal ini dikarenakan sektor pertanian memberikan kontribusi terbesar bagi perekonomian di Indonesia, sehingga perlu penanganan khusus bagi sektor pertanian agar sektor tersebut tetap bertahan sebagai sektor unggulan. Sebagai leading sector, pertanian memiliki peluang yang diperhitungkan dalam pembangunan pertanian.

Salah satu sub sector andalan di sector pertanian yang mendapatkan perhatian sebagai penyerap tenagakerja di wilayah pedesaan adalah sub sector perkebunan. Komoditas tembakau merupakan salah satu produk sub sector perkebunan yang kontribusinya terhadap perekonomian nasional cukup tinggi. Peranan makro komoditas tembakau dan sektor-sektor yang terkait dengan tembakau dapat dilihat dari besarnya perubahan dalam output, pendapatan, dan penyerapan tenaga kerja sebagai respon sumberdaya potensial dan aktual terhadap perubahan ekonomi (West, 1993).

Tembakau menjadi komoditas perkebunan dengan produksi tertinggi di Kabupaten Situbondo dengan produksi 2.389.342 ton/tahun.Produksi tembakau yang tinggi di Kabupaten Situbondo tidak terlepas dari peran Kecamatan Suboh sebagai Kecamatan dengan produksi tembakau tertinggi di Kabupaten Situbondo dengan 1088 622 ton.

Ketenagakerjaan merupakan salah satu hal penting yang perlu diperhatikan dalam masalah pembangunan. Penyerapan tenaga kerja diperlukan dalam distribusi pendapatan yang nantinya akan berdampak pada pembangunan. Pendapatan yang diperoleh masyarakat, hampir seluruhnya berasal dari upah yang diberikan dilapangan pekerjaan. Jumlah pendapatan yang diterima tenaga kerja tersebut menentukan besarnya kemakmuran dari suatu masyarakat. Semakin tinggi pendapatan perkapita suatu masyarakat maka semakin tinggi tingkat kemakmurannya. Suatu proses pembangunan melakukan perubahan mendasar atas struktur sosial, sikap-sikap masyarakat, dan institusi nasional yang juga tetap memperhatikan pertumbuhan ekonomi, penanganan ketimpangan pendapatan, serta pengentasan kemiskinan (Todaro, 2000).

Penyerapan tenaga kerja sub sektor pertanian masih ada ketimpangan, bidang ini masih banyak dijumpai kesenjangan/ketidakadilan gender. Minimnya partisipasi perempuan dalam proses pembangunan khususnya bidang pertanian, membuat programprogram yang dijalankan kurang dapat memberikan keadilan kepada perempuan. Pengambil kebijakan umumnya telah membuat banyak kebijakan berkaitan dengan partisipasi perempuan dan keadilan gender untuk pelaksanaan program. Akan tetapi di tingkat pelaksana lapangan ada kesulitan untuk mengimplementasikan program secara lebih berpartisipatif dan berkeadilan bagi perempuan (Anonimus, 2007)

Sebagai contoh upah buruh tani perempuan jauh lebih rendah dibanding laki-laki dalam jenis pekerjaan dan jam kerja yang sama. Hal ini terjadi karena adanya anggapan bahwa fisik laki-laki lebih kuat, sehingga dianggap berhak atas upah yang lebih tinggi. Bahkan sering tidak adanya pengakuan terhadap pekerjaan perempuan, terutama di sektor pertanian karena pekerjaan pertanian dianggap sebagai pekerjaan laki-laki. Oleh karena itu, seberat apapun perempuan bekerja di pertanian tetap dianggap sebagai pembantu suami (kepala keluarga) (Arjani, 2006).

Berdasarkan penjelasan yang telah dipaparkan diatas, maka dapat diidentifikasikan rumusan masalah sebagai berikut : 1) Berapa penyerapan tenaga kerja laki-laki (L) dan perempuan (P) pada berbagai tahapan kegiatan usahatani tembakau mulai dari persiapan lahan sampai dengan pemasaran dalam usahatani tembakau? 2) Bagaimanakah curahan jam kerja antara laki-laki (L) dan perempuan (P)dalam usahatani tembakau? 3) Bagaimanakah besaran upah bagi tenaga kerja laki-laki (L) dan perempuan (P) dalam usahatani tembakau? 


\section{METODE PENELITIAN}

Metode deskriptif yaitu suatu metode dalam meneliti status sekelompok manusia, suatu objek, suatu set kondisi, suatu sistem pemikiran ataupun suatu kelas peristiwa pada masa sekarang. Metode tersebut bertujuan untuk membuat deskripsi, gambaran atau lukisan secara sitematis, faktual dan akurat mengenai fakta daerah tertentu. Teknik pengumpulan data melalui kegiatan: dokumentasi, wawancara, dan observasi. Teknik analisis menggunakan pendekatan analisis kuantitatif deskriptif.

\section{HASIL DAN PEMBAHASAN}

Dinamika penyerapan tenaga kerja dan kesempatan kerja di wilayah pedesaan sangat dipengaruhi oleh kondisi agroekosistem setempat. Agroekosistem lahan sawah dipengaruhi oleh tipe irigasi, struktur penguasaan lahan pertanian, system usahatani, pola tanam dan siklus tanam, dan komoditas dominan yang diusahakan, serta system pola hubungan kerja. Intensitas tanam yang lebih tinggi yang tergambarkan dalam siklus dan pola tanam akan mempunyai daya serap terhadap penyerapan kesempatan kerja yang lebih tinggi.

\section{Penyerapan Tenaga Kerja pada Kegiatan Usahatani Tembakau.}

Sampai dengan saat ini sector perkebunan tetap menyerap tenaga kerja terbesar dan menjadi penopang perekonomian di pedesaan.Data proporsi jumlah tenaga kerja berdasarkan gender dan tahapan pekerjaan pada pengusahaan tembakau sebagai berikut.

Tabel 1. Jumlah Tenaga Kerja Berdasarkan gender pada Pengusahaan Tembakau di Desa Suboh dengan luas lahan $1 \mathrm{Ha}$

\begin{tabular}{|c|c|c|c|c|c|}
\hline \multirow[b]{2}{*}{ No } & \multirow[b]{2}{*}{ Jenis Tahapan } & \multicolumn{2}{|c|}{ Jumlah TK } & \multirow{2}{*}{\multicolumn{2}{|c|}{$\begin{array}{c}\text { Persentase } \\
(\%)\end{array}$}} \\
\hline & & $\mathrm{L}$ & $\mathrm{P}$ & & \\
\hline 1 & Pembuatan Bedengan & 25 & - & 100 & - \\
\hline 2 & Pembuatan gulutan & 25 & - & 100 & - \\
\hline 3 & Penanaman & 20 & 13 & 61 & 39 \\
\hline 4 & Pemupukan dasar & 8 & 3 & 73 & 27 \\
\hline 5 & Pemupukan Lanjutan 1 & 8 & 3 & 73 & 27 \\
\hline 6 & Pemupukan Lanjutan 2 & 8 & 3 & 73 & 27 \\
\hline 7 & Pengairan kocor & 8 & 5 & 62 & 38 \\
\hline 8 & Pembersihan gulma & 10 & 13 & 43 & 57 \\
\hline 9 & Pembumbunan & 25 & - & 100 & - \\
\hline 10 & Aplikasi CPA (pestisida) & 5 & - & 100 & - \\
\hline 11 & Topping (Munggel) & 5 & 8 & 38 & 62 \\
\hline 12 & Suckering (Wiwilan) & 5 & 8 & 38 & 62 \\
\hline \multirow[t]{2}{*}{13} & Panen & 13 & 13 & 50 & 50 \\
\hline & Total & 165 & 69 & 71 & 29 \\
\hline
\end{tabular}

Sumber: Data Primer Penelitian Desa Suboh Kecematan Suboh 2018

Tabel 1 menjelaskan adanya perbedaan penyerapan tenaga kerja laki-laki dan tenaga kerja perempuan disetiap pekerjaan tembakau. Total penyerapan tenaga kerja laki-laki lebih besar dari tenaga kerja perempuan. Tenaga kerja laki-laki sebesar 71 \% (165 orang) dam tenaga kerja perempuan 29 \% (69 orang). Perbedaan disebabkan karena adanya peran dan tugas masing-masing tenaga kerja laki-laki dan tenaga kerja perempuan. 


\section{Curahan Jam Kerja Antara Laki-Laki dan Perempuan dalam usahatani Tembakau} dibawah ini.

Curahan jam kerja pada berbagai tahapan kegiatan dapat dilihat pada tabel 5.3

Tabel 2. Proporsi Curahan Jam Kerja Tenaga Kerja Laki-Laki Dan Perempuan Pada Usahatani Tembakau di Desa Suboh dengan luas lahan $1 \mathrm{Ha}$

\begin{tabular}{llrr}
\hline \multirow{2}{*}{ No } & \multicolumn{1}{c}{ Jenis Tahapan } & L & \multicolumn{2}{c}{$\mathrm{P}$} \\
\cline { 3 - 4 } $\mathbf{1}$ & Lapang & & - \\
& a. Pembuatan Bedengan & 24,6 & - \\
& b. Pembuatan gulutan & 12,5 & 12,5 \\
& c. Penanaman & 12,5 & 1,75 \\
d. Pemupukan dasar & 12,5 & 1,75 \\
e. Pemupukan Lanjutan 1 & 12,5 & 1,75 \\
f. Pemupukan Lanjutan 2 & 12,5 & 10 \\
g. Pengairan kocor & 12,5 & 22,5 \\
h. Pembersihan gulma & 22,5 & - \\
i. Pembumbunan & 19,37 & 28,5 \\
j. Aplikasi CPA (pestisida) & 12,5 & 28,5 \\
k. Topping (Munggel) & 1,25 & 12,5 \\
l. Suckering (Wiwilan) & 1,25 & 119,75 \\
m. Panen & 12,5 & \\
\hline & Total & 178,97 &
\end{tabular}

Sumber: Data Primer Penelitian Desa Suboh Kecematan Suboh 2018

Perbedaan curahan jam kerja antara tenaga kerja laki-laki dan perempuan pada setiap tahapan usahatani tembakau. Total curahan jam kerja laki-laki lebih besar dari tenaga kerja perempuan. Tenaga kerja laki-laki sebesar 178,97 jam dan tenaga kerja perempuan sebesar 119,75 jam. Hal tersebut disebabkan karena adanya perbedaan jumlah penyerapan tenaga kerja laki-laki dan perempuan (Tabel 1). Jumlah penyerapan tenaga kerja laki-laki yang lebih besar dari tenaga kerja perempuan berpengaruh terhadap curahan tenaga kerja. Dapat disimpulkan curahan jam kerja laki-laki lebih besar dari tenaga kerja perempuan pada usatani tembakau yang dipengaruhi oleh adanya perbedaan jumlah penyerapan tenaga karja laki-laki dan perempuan.

\section{Besaran Upah bagi Tenaga Kerja Laki-Laki dan Perempuan dalam Usahatani Tembakau.}

Pada usahatani tembakau, besaran upah tenaga kerja yang diterima sudah termasuk besaran upah tambahan lainnya. Nilai besaran upah tambahan lainnya yang diberikan oleh petani pemilik kepada masing-masing pekerja berbeda-beda, tergantung porsi kerja masing-masing pekerja. Besaran upah tambahan lainnya tersebut meliputi rokok dikonversikan dalam bentuk nilai angka rupiah sehingga diperoleh nilai besaran upah yang diterima oleh masing-masing pekerja. 
Tabel 3. Besaran Upah Tenaga Kerja Laki-Laki Dan Tenaga Kerja Perempuan Pada Usaha Tani Tembakau Per 5 Jam Kerja di Desa Suboh.

\begin{tabular}{|c|c|c|c|c|c|c|c|}
\hline \multirow[b]{2}{*}{ No } & \multirow[b]{2}{*}{ Jenis Tahapan } & \multicolumn{2}{|c|}{ Upah TK } & \multirow[b]{2}{*}{ Total } & \multicolumn{2}{|c|}{ Tambahan } & \multirow[b]{2}{*}{ Total } \\
\hline & & Upah & Tambah & & Upah & Tambah & \\
\hline 1 & Pembuatan Bedengan & 30.000 & 3.000 & 33.000 & - & & - \\
\hline 2 & Pembuatan gulutan & 30.000 & 3.000 & 33.000 & - & & - \\
\hline 3 & Penanaman & 30.000 & 3.000 & 33.000 & 30.000 & & 30.000 \\
\hline 4 & Pemupukan dasar & 30.000 & 3.000 & 33.000 & 30.000 & & 30.000 \\
\hline 5 & $\begin{array}{l}\text { Pemupukan Lanjutan } \\
1\end{array}$ & 30.000 & 3.000 & 33.000 & 30.000 & & 30.000 \\
\hline 6 & $\begin{array}{l}\text { Pemupukan Lanjutan } \\
2\end{array}$ & 30.000 & 3.000 & 33.000 & 30.000 & & 30.000 \\
\hline 7 & Pengairan kocor & 30.000 & 3.000 & 33.000 & 30.000 & & 30.000 \\
\hline 8 & Pembersihan gulma & 30.000 & 3.000 & 33.000 & 30.000 & & 30.000 \\
\hline 9 & Pembumbunan & 30.000 & 3.000 & 33.000 & - & & - \\
\hline 10 & $\begin{array}{l}\text { Aplikasi CPA } \\
\text { (pestisida) }\end{array}$ & 30.000 & 3.000 & 33.000 & - & & - \\
\hline 11 & Topping (Munggel) & 30.000 & 3.000 & 33.000 & 30.000 & & 30.000 \\
\hline 12 & Suckering (Wiwilan) & 30.000 & 3.000 & 33.000 & 30.000 & & 30.000 \\
\hline 13 & Panen & 30.000 & 3.000 & 33.000 & 30.000 & & 30.000 \\
\hline & Total & 390.000 & 39.000 & 660.000 & 270.000 & & 270.000 \\
\hline
\end{tabular}

Sumber: Data Primer Penelitian Desa Suboh Kecematan Suboh 2018

Besaran upah tenaga kerja berdasarkan 5 jam kerja/hari menunjukkan bahwa upah tenaga kerja ada perbedaan. Perberbedaan disebabkan karena uang tambahan dari tenaga kerja laki-laki yaitu 3.000,. uang tambahan tersebut ialah uang rokok setiap 5 jam kerja masing-masing tenaga kerja menghabiskan 2 batang rokok dimana masing-masing batang rokok bernilai 1.500,. untuk besaran upah pada umumnya sama dengan upah 30.000 per 5 jam kerja.

Kontribusi tembakau terhadap pendapatan keluarga sebesar 70 \% (Lampiran 3), responden yang dimaksud yaitu petani buruh. Data diambil dari pendapatan sebelum musim tembakau dan sesudah musim tembakau. Hal tersebut disebabkan karena pada musim tanam tembakau petani buruh hampir setiap hari kerja dibandingkan sebelum musim tanam tembakau.

\section{KESIMPULAN}

Berdasarkan hasil analisis dan pembahasan, maka dapat diambil beberapa

kesimpulan sebagai berikut:

1. Penyerapan tenaga kerja laki-laki dan perempuan pada usahatani tembakau mulai dari persiapan lahan sampai dengan panen dalam usahatani tembakau yang telah dikonversiakan menjadi 1 hektaryaitu tenaga kerja laki-laki sebesar 71 \% (165 orang) dan tenaga kerja perempuan $29 \%$ (69 orang).

2. Curahan jam kerja antara laki-laki dan perempuan dalam usahatani tembakau tidak ada perbedaan karena didalam curahan jam antara laki-laki dan perempuan sama yaitu 5 jam per hari

3. Upah tenaga kerja laki-laki lebih besar daripada tenaga kerja perempuan, 33.000 untuk tenaga kerja laki-laki dan 30.000 untuk tenaga kerja perempuan. Dengan kontribusi tembakau terhadap pendapatan keluarga sebesar 70\%. 


\section{REFERENSI}

Anonimous, 2007, Buku Panduan: Pengintegrasian Gender dalam Program Pertanian, Irigasi dan Perikanan, Tim Relawan Perempuan untuk Kemanusiaan (RPUK) dan Black \& Veatch

Arjani, N.L. 2006. "Ketimpangan Gender di Beberapa Bidang Pembangunan" http://ejournal.unud.ac.id/

BPS. 2018. Kabupaten Situbondo dalam Angka tahun 2017. Situbondo: BPS

Todaro S. 2000. Pembangunan Ekonomi di Dunia Ketiga. Edisi Ke-7. Munandar [penerjemah]. Jakata: IPB Press

West, G.R. 1993. "GRIMP: Input-Output Analysis for Practitioners. Version 7.1. User'sGuide". Department of Economics, University of Queensland, Queensland 